Indonesian Journal of Biotechnology, June, 2013

Vol. 18, No. 1, pp.42-51

\title{
Apolipoprotein E as Risk Factor for Coronary Heart Disease
}

\author{
Pramudji Hastuti ${ }^{1}$, Abdul Salam Mudzakir Sofro ${ }^{2}$, Ahmad Husain Asdie ${ }^{3}$, \\ and Ahmad Hamim Sadewa ${ }^{1}$
}

\begin{abstract}
${ }^{1}$ Department of Biochemistry, Faculty of Medicine, Universitas Gadjah Mada, Yogyakarta, Indonesia ${ }^{2}$ Faculty of Medicine, Universitas YARSI, Jakarta, Indonesia

${ }^{3}$ Department of Internal Medicine, Faculty of Medicine, Universitas Gadjah Mada, Yogyakarta, Indonesia
\end{abstract}

\begin{abstract}
Allelic variation of apolipoprotein E (apo E) has been shown to influence the concentrations of total cholesterol and low density lipoprotein cholesterol (LDL-C) and considered to play a role as one of risk factors for coronary heart disease (CHD). The aim of this study was to examine the relationship between Apo E polymorphism and the risk of CHD. Blood samples were collected from 33 CHD patients in Dr. Sardjito Hospital Yogyakarta, and 38 apparently healthy control individuals in a cross sectional study. The common allelic variants of ApoE were screened employing polymerase chain reaction and restriction fragment length polymorphism. The results obtained were analyzed by t-test and significantly different if $\mathrm{p}<0.05$ and risk factor was calculated by odd ratio. Frequency of $A p o E \varepsilon 2, \varepsilon 2$ and $\varepsilon 4$ alleles in CHD patients were $12.1 \%, 69.7 \%$ and $18.2 \%$ while in controls were $18.4 \%, 72.4 \%$ and $9.2 \%$ respectively. Dyslipidemia condition was a strong risk factor for CHD. By controlling lipid profile and applying multifactorial statistic analysis, it was shown that $\varepsilon 4$ gene carrier was the risk factor for $\mathrm{CHD}$, but not in triglyceride level, whereas $\varepsilon 2$ carrier gene was not the risk factor for CHD. Dislipidemia was the risk factor for $\mathrm{CHD}$ and $A p o E \varepsilon 4$ gene carrier was the risk factor for CHD.
\end{abstract}

Key words: apolipoprotein E, ApoE $\varepsilon 4$ gene carrier, coronary heart disease, dyslipidemia.

\section{Introduction}

Apolipoprotein E (apoE) is a protein constituent of plasma lipoproteins that performs several functions including a role in cholesterol metabolism and as an important ligand inlipoproteinclearance. Apolipoprotein $E$ was first identified as a constituent of very low density lipoprotein (VLDL) which function to transport triglycerides from the liver to peripheral tissues (Mayes and Botham, 2006). Apolipoprotein $E$ gene is polymorphic and exists in six different isoform proteins, designated E2/E2,E2/E3,E2/E4,E3/E3, E3/

*Corresponding author :

Pramudji Hastuti

Department of Biochemistry, Faculty of Medicine, UGM, Sekip Utara Yogyakarta.

Phone 62-0274-6492446,

E-mail: hpramudji@yahoo.com
$\mathrm{E} 4$, and E4/E4 which are the gene products of three ApoE alleles i.e. $\varepsilon 2, \varepsilon 3$ and $\varepsilon 4$ respectively (Belkovets et al., 2001). Apolipoprotein E2 exhibits lower affinity for the LDL receptor, resulting in slower clearance of ApoE and higher plasma apoE levels. Conversely, ApoE4 is cleared more efficiently, resulting in lower ApoE levels and higher cholesterol levels. The genetic variations thus affect lipid metabolism and have been shown to alter risk of cardiovascular disease and dementia (Eichner et al., 2002).

Epidemiologic studies addressing the contribution of apo $\varepsilon$ gene to Coronary Heart Disease (CHD), reported that $\sim 6$ percent of the variation in risk for CHD in North America can be attributed to this locus. Another study of middle-aged men from nine populations estimated a $\sim 40$ percent increased risk for CHD mortality for $\varepsilon 4$ carriers compared with 
$\varepsilon 3$ carriers or $\varepsilon 2$ carriers (Stengard et al., 1998). Some studies have also suggested that $\varepsilon 4$ carriers are particularly prone to developing disseminated coronary lesions or to havean increased risk of death from CHD (Eichner et al., 1993, Lehtinen et al., 1995; Stengard et al., 1995, Wang et al., 1995). Coronary heart disease is related to dysfunction of the E4 isoform in lipoprotein metabolism and an increased concentration of serum cholesterol and triglycerides. Studies from Finland, Scotland, and northern part of Ireland have shown that populations with higher cholesterol levels and higher CHD mortality rates also have a higher frequency of the $\varepsilon 4$ allele. Other studies have also associated the $\varepsilon 2$ allele with increased CHD risk (Eichner et al., 2002, Zannis et al., 1996, Mahley et al., 2006).

An association between apoE $\varepsilon 2 / \varepsilon 2$ and type III hyperlipoproteinemia has been known for decades. This disorder is characterized by increased cholesterol and triglyceride levels, the presence of $B-V L D L$ (cholesterol-enriched remnants of intestinal chylomicrons and hepatic VLDL), xanthomas, and premature vascular disease, both $\mathrm{CHD}$ and peripheral artery disease (Mahley et al., 1995). Overt hyperlipoproteinemia III occurs with a frequency of $1-5$ per 5,000 , whereas homozygosity for E2/ 2 occurs with a frequency of 0.5-1.0 per 100 in Caucasian populations. Thus, this genotype contributes to the hyperlipoproteinemia III phenotype without being its sole cause (Eichner et al., 2002, Fullerton et al., 2000). It examines the relationship of this genotype in $\mathrm{CHD}$ patients compared to the specified controls.

\section{Materials and Methods}

Blood samples were collected from CHD patients in Dr. Sardjito Hospital Yogyakarta compared with controls collected from an exersice group in Yogyakarta.

Inclusion criteria: patients were diagnosed by an Internal Medicine Specialist as CHD, Javanese male or female age 40 75 years, BMI <30, and free from Diabetes
Mellitus (DM). Exclusion criteria: CHD patients with DM and non Javanese ethnic background. Inclusion criteria for the control group: apparently healthy male or female individuals, BMI < 30, no DM, age $40-75$ years and Javanese ethnic in origin. Exclusion criteria: DM and non Javanese.

Plasma from patients and controls were separated and their lipid profiles were examined. Buffy coat from patients and controls were prepared for DNA isolation. Polymerase Chain Reaction (PCR) was performed with Zivelin et al., (1997) method to amplify exon 4 and then followed by HaeII dan Afl III digestion to identify the $\varepsilon 2, \varepsilon 3$ and $\varepsilon 4$ allele with 195 and $23 \mathrm{bp}$ for $\varepsilon 4 ; 23,50$ and $145 \mathrm{bp}$ for $\varepsilon 3$ and 50 and $168 \mathrm{bp}$ for $\varepsilon 2$ respectively. Genotype of $\varepsilon 2 / \varepsilon 2$ and $\varepsilon 2 / \varepsilon 3$ were grouped as $\varepsilon 2$ carrier; genotype of $\varepsilon 3 / \varepsilon 3$ was grouped as $\varepsilon 3$ carrier and genotype of $\varepsilon 3 / \varepsilon 4$ and $\varepsilon 4 / \varepsilon 4$ were grouped as $\varepsilon 4$ carrier. ApoE $\varepsilon 2 / \varepsilon 4$ was not included as any apoE carrier. The result was analyzed employing t-test to compare lipid profile in CHD patients and controls with significant difference at $p<0.05$. Odd Ratio was used to determine the risk factors, while Chi Square test was used for frequency of $a p o E$ genotype and allele as risk factor of CHD. Another Odd Ratio was apllied to analyse apoE genotype and allele as risk factor of $\mathrm{CHD}$ with controlled lipid profile.

\section{Results}

Apolipoprotein E polymorphism was examined in $33 \mathrm{CHD}$ patients and 38 controls. There were no significant difference between patients and controls in the body weight, height, BMI, blood pressure and blood glucose with t-test $p>0.05$ (Table 1 ).

There were no significant difference between CHD patients and controls in their lipid profile $(p>0.05)$ despite higher levels of triglyceride, cholesterol, and LDL-C and lower level of HDL-C in CHD patients (Table 2 and Figure 1).

When Chi square analysis was employed, higher frequency of dyslipidemia in CHD patients was observed with 
Table 1. Sex, age, body weight, height, blood pressure, and blood glucose level in CHD patients and control

\begin{tabular}{lccc}
\hline & $\begin{array}{c}\text { CHD patients } \\
(\mathrm{n}=33)\end{array}$ & $\begin{array}{c}\text { Control } \\
(\mathrm{n}=38)\end{array}$ & $\mathrm{P}$ \\
\hline Men & 20 & 22 & 0.992 \\
Women & 13 & 16 & \\
Age (year) & $60.5 \pm 9.2$ & $57.9 \pm 8.60$ & 0.843 \\
Body Weight $(\mathrm{kg})$ & $63.23 \pm 9.26$ & $62.56 \pm 9.30$ & 0.754 \\
Height $(\mathrm{m})$ & $1.62 \pm 0.05$ & $1.61 \pm 0.053$ & 0.400 \\
BMI $\left(\mathrm{kg} / \mathrm{m}^{2}\right)$ & $24.01 \pm 3.08$ & $24.0 \pm 3.35$ & 0.989 \\
Systolic BP $(\mathrm{mmHg})$ & $141.0 \pm 17.88$ & $137.31 \pm 19.56$ & 0.394 \\
Dyastolic BP $(\mathrm{mmHg})$ & $84.0 \pm 10.70$ & $89.04 \pm 12.96$ & 0.069 \\
Blood glucose $(\mathrm{mg} / \mathrm{dL})$ & $112.4 \pm 14.70$ & $104.3 \pm 12.5$ & 0.086 \\
\hline
\end{tabular}

Table 2. Lipid profile in CHD patients and controls

\begin{tabular}{lllc}
\hline & CHD $(\mathrm{n}=33)$ & \multicolumn{1}{c}{ Control $(\mathrm{n}=38)$} & $\mathrm{P}$ \\
\hline Triglyceride $(\mathrm{mg} / \mathrm{dL})$ & $136.8 \pm 56.6$ & $123.47 \pm 63.98$ & 0.680 \\
Cholesterol total $(\mathrm{mg} / \mathrm{dL})$ & $196.1 \pm 37.3$ & $169.9 \pm 39.4$ & 0.657 \\
LDL-C $(\mathrm{mg} / \mathrm{dL})$ & $121.8 \pm 37.3$ & $102.69 \pm 50.16$ & 0.527 \\
HDL-C $(\mathrm{mg} / \mathrm{dL})$ & $44.8 \pm 12.5$ & $49.6 \pm 10.1$ & 0.256 \\
\hline
\end{tabular}

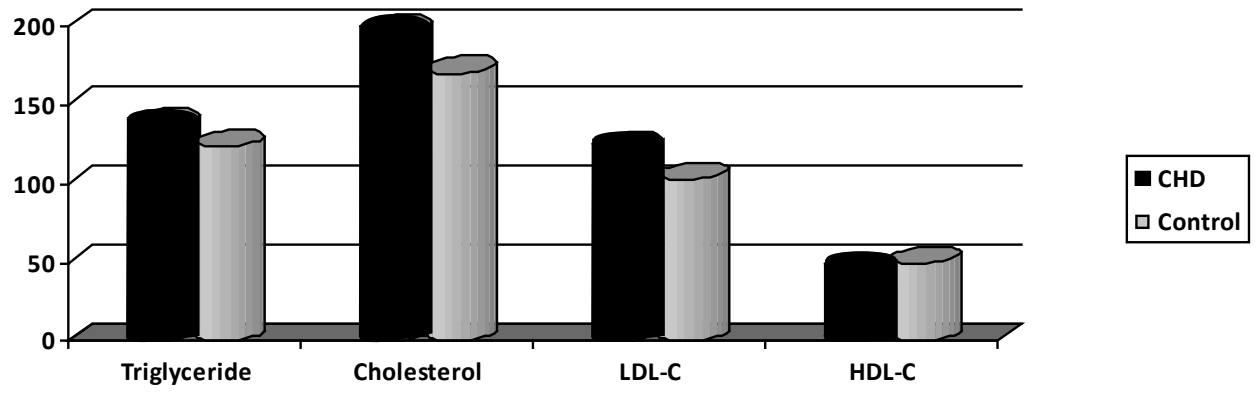

Figure 1. Lipid profiles in CHD and control

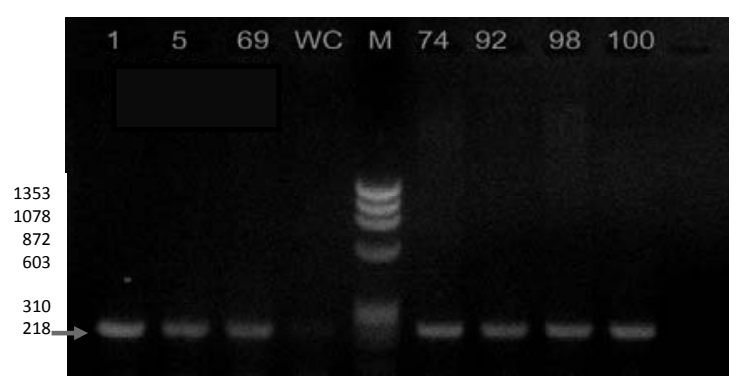

Figure 2. PCR result of apoE (218 base pair) $(1,5,69$, 74, 92, 98 and 100 were PCR result with $218 \mathrm{bp}$, WC was water control, $\mathrm{M}=$ marker $\Phi \times 174$ )

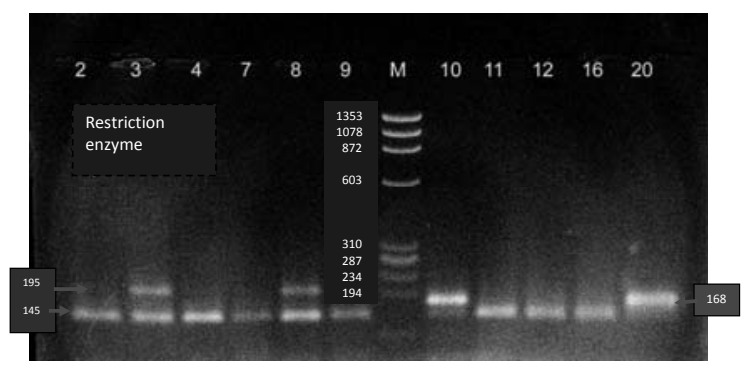

Figure 3. Result of PCR after digested by Afl III and Hae II enzymes (No 2, 4, 7, 9, 11, 12, 16 were $E$ \&3-3 genotype, no 3 and 8 were apoE $\varepsilon 3-4$ genotype, no 10 was apoE $\varepsilon 2-3$ genotype, no 20 was apoE $\varepsilon 2-2$ geneotype, and $\mathrm{M}$ was marker $\Phi \times 174)$. 
Table 3. Odd Ratio of lipid profile between CHD and controls

\begin{tabular}{cccc}
\hline & CHD & CONTROL & OR (Cl 95\%) \\
& $\mathrm{N}=33$ & $\mathrm{~N}=38$ & $3.93(1.15-13.5)$ \\
\hline Cholesterol $>200 \mathrm{mg} / \mathrm{dL}$ & 14 & 6 & \\
$<200 \mathrm{mg} / \mathrm{dL}$ & 19 & 32 & $1.40(0.45-4.40)$ \\
Triglyceride $>150 \mathrm{mg} / \mathrm{dL}$ & 11 & 10 & \\
$<150 \mathrm{mg} / \mathrm{dL}$ & 22 & 28 & $3.05(0.88-10.94)$ \\
HDL-C $<40 \mathrm{mg} / \mathrm{dL}$ & 12 & 6 & \\
$>40 \mathrm{md} / \mathrm{dL}$ & 21 & 32 & $1.60(0.52-4.98)$ \\
LDL-C $>130 \mathrm{mg} / \mathrm{dL}$ & 12 & 10 & \\
$<130 \mathrm{mg} / \mathrm{dL}$ & 21 & 28 & \\
\hline
\end{tabular}

Table 4. Polymorphism of apoE in CHD and control

\begin{tabular}{lllcc}
\hline & \multicolumn{1}{c}{ CHD (33) } & \multicolumn{1}{c}{ Control (38) } & \multicolumn{1}{c}{ OR (Cl 95\%) } & P \\
\hline Genotype & $\varepsilon 2 / \varepsilon 2: 1(3.1 \%)$ & $\varepsilon 2 / \varepsilon 2: 4(10.5 \%)$ & $0.26(0.01-2.68)$ & 0.082 \\
& $\varepsilon 2 / \varepsilon 3: 6(18.1 \%)$ & $\varepsilon 2 / \varepsilon 3: 5(13.2 \%)$ & $1.47(0.34-6.36)$ & \\
& $\varepsilon 2 / \varepsilon 4:-$ & $\varepsilon 2 / \varepsilon 4: 1(2.6 \%)$ & - & \\
& $\varepsilon 3 / \varepsilon 3: 14(42.4 \%)$ & $\varepsilon 3 / \varepsilon 3: 23(60.6 \%)$ & 1.00 & \\
& $\varepsilon 3 / \varepsilon 4: 12(36.4 \%)$ & $\varepsilon 3 / \varepsilon 4: 4(10.5 \%)$ & $4.86(1.22-20.83)$ & \\
& $\varepsilon 4 / \varepsilon 4:-$ & $\varepsilon 4 / \varepsilon 4: 1(2.6 \%)$ & - & 0.078 \\
\hline Gene carrier & $\varepsilon 2: 7(21.2 \%)$ & $\varepsilon 2: 9(24.3 \%)$ & $1.28(0.40-4.07)$ & \\
& $\varepsilon 3: 14(42.4 \%)$ & $\varepsilon 3: 23(62.2 \%)$ & 1.00 & \\
& $\varepsilon 4: 12(36.4 \%)$ & $\varepsilon 4: 5(13.5 \%)$ & $3.94(0.99-16.48)$ & \\
\hline Alelle & $\varepsilon 2: 8(12.1 \%)$ & $\varepsilon 2: 14(18.4 \%)$ & $0.68(0.24-1.94)$ & 0.216 \\
& $\varepsilon 3: 46(69.7 \%)$ & $\varepsilon 3: 55(72.4 \%)$ & & 1.00 \\
& $\varepsilon 4: 12(18.2 \%)$ & $\varepsilon 4: 7(9.2 \%)$ & $2.05(0.68-6.35)$ & \\
\hline
\end{tabular}

significant difference $(p<0.05)$ in cholesterol concentration. Applying Odd Ratio calculation, it was showed that dyslipidemia was a strong risk factor for CHD with 1.4 3.93 times higher (Table 3 )

The result of PCR (Figure 2) was digested by Afl III and Hae II to determine the apoE $\varepsilon 2$, apo $E \varepsilon 3$, and $a p o E \varepsilon 4$ genotypes (Figure 3).

The frequency of apoE $\varepsilon 2 / \varepsilon 2$, apoE $\varepsilon 2 /$ $\varepsilon 3$, apoE $\varepsilon 3 / \varepsilon 3$, and $a p o E \varepsilon 3 / \varepsilon 4$ genotypes in CHD patients were $3.1 \%, 18.1 \%, 42.4 \%$ and $36.4 \%$, respectively and in controls were $10.5 \%, 13.2 \%, 60.6 \%$, and $15.7 \%$. ApoE ع $2 / \varepsilon 4$ and apoE $\varepsilon 4 / \varepsilon 4$ genotypes were not found in CHD patients. Comparison was not possible. Significant difference $(p<0.05)$ was only observed in apoE $\varepsilon 3 / \varepsilon 4$ genotype with OR 4.86 times higher than other genotypes between $\mathrm{CHD}$ patients and controls. Apolipoprotein $E$ $\varepsilon 2 / \varepsilon 2$ genotype in CHD patients showed OR $<1$, indicating that apoE $\varepsilon 2 / \varepsilon 2$ genotype was protective factor for CHD (Table 4 ).
On the other hand, despite $\mathrm{p}>0.05$ for $\varepsilon 4$ allele, OR 2.05 indicates its role as risk factor for CHD. It can be summarized that apoE $\varepsilon 3 /$ $\varepsilon 4$ genotype and $\varepsilon 4$ allele were risk factors for $\mathrm{CHD}$, whereas apoE $\varepsilon 2 / \varepsilon 2$ genotype and $\varepsilon 2$ allele were protective factors for $\mathrm{CHD}$.

Being as risk factor for CHD, dyslipidemic condition especially the increase of cholesterol and LDL-C as well as the decrease of HDL-C levels were risk factors for CHD for all of apoE genotypes (Tabel 5, 6, and 7). In contrast, the increase of triglyceride level in $\varepsilon 2$ carrier gene was not the risk factor for CHD (Table 8).

Table 5 showed the relation of apoE polymorphism with hypercholesterolemia which is 5 and 7.88 times higher to have CHD in high concentration of cholesterol but in the case of $\varepsilon 4$ carrier the OR of this gene carrier could not be calculated due to low level of cholesterol in the control group. This result summarized that hypercholesterolemia caused CHD in all of apoE gene carrier. 
Table 5. Risk factor of apoE polymorphism to high level of cholesterol in CHD patients and control

\begin{tabular}{cccc}
\hline ApoE gene carrier & $\begin{array}{c}\text { CHD } \\
\text { patients }\end{array}$ & Control & OR $(\mathrm{Cl} \mathrm{95 \% )}$ \\
\hline CHOLESTEROL & & & \\
$\varepsilon 2,>200 \mathrm{mg} / \mathrm{dL}$ & 5 & 3 & $5.00(0.40-81.88)$ \\
$\varepsilon 2,<200 \mathrm{mg} / \mathrm{dL}$ & 2 & 6 & \\
$\varepsilon 3,>200 \mathrm{mg} / \mathrm{dL}$ & 6 & 2 & $7.88(1.06-72.78)$ \\
$\varepsilon 3,<200 \mathrm{mg} / \mathrm{dL}$ & 8 & 21 & - \\
$\varepsilon 4,>200 \mathrm{mg} / \mathrm{dL}$ & 4 & 0 & \\
$\varepsilon 4,<200 \mathrm{mg} / \mathrm{dL}$ & 8 & 5 & \\
\hline
\end{tabular}

Table 6. Risk factor of ApoE polymorphism in LDL-C level in CHD patients and Control

\begin{tabular}{cccc}
\hline $\begin{array}{c}\text { ApoE gene } \\
\text { carrier }\end{array}$ & $\begin{array}{c}\text { CHD } \\
\text { patients }\end{array}$ & Control & OR (Cl95\%) \\
\hline LDL-C & & & \\
$\varepsilon 2,>130 \mathrm{mg} / \mathrm{dL}$ & 5 & 3 & $5.00(0.4-81.88)$ \\
$\varepsilon 2,<130 \mathrm{mg} / \mathrm{dL}$ & 2 & 6 & \\
$\varepsilon 3,>130 \mathrm{mg} / \mathrm{dL}$ & 2 & 5 & $0.60(0.07-4.51)$ \\
$\varepsilon 3,<130 \mathrm{mg} / \mathrm{dL}$ & 12 & 18 & \\
$\varepsilon 4,>130 \mathrm{mg} / \mathrm{dL}$ & 5 & 1 & $2.86(0.17-90.96)$ \\
$\varepsilon 4,<130 \mathrm{mg} / \mathrm{dL}$ & 7 & 4 & \\
\hline
\end{tabular}

Table 6 showed that high level of LDL-C was risk factor for $\mathrm{CHD}$ with $\varepsilon 2$ and $\varepsilon 4$ alleles, but not for $\varepsilon 3$ allele. In low HDL-C level, individual with $\varepsilon 2$ and $\varepsilon 3$ alleles were at risk for CHD (Table 7).

Table 7. Risk factor for apoE polymorphism in HDL-C level in CHD patients and control

\begin{tabular}{cccc}
\hline $\begin{array}{c}\text { ApoE carrier } \\
\text { genee }\end{array}$ & CHD & Control & OR $(\mathrm{Cl} 95 \%)$ \\
\hline HDL-C & & & \\
$\varepsilon 2,<40 \mathrm{mg} / \mathrm{dL}$ & 3 & 1 & $6.00(0.33-214.95)$ \\
$\varepsilon 2,>40 \mathrm{mg} / \mathrm{dL}$ & 4 & 8 & \\
$\varepsilon 3,<40 \mathrm{mg} / \mathrm{dL}$ & 6 & 3 & $5.00(0.80-34.52)$ \\
$\varepsilon 3,>40 \mathrm{mg} / \mathrm{dL}$ & 8 & 20 & \\
$\varepsilon 4,<40 \mathrm{mg} / \mathrm{Dl}$ & 3 & 1 & $1.33(0.07-45.29)$ \\
$\varepsilon 4,>40 \mathrm{mg} / \mathrm{dL}$ & 9 & 4 & \\
\hline
\end{tabular}

Table 8 showed that high level of triglyceride was the risk factor for CHD with $\varepsilon 3$ and $\varepsilon 4$ alleles, but not for $\varepsilon 2$ allele.

The overall OR of lipid profile showed $\varepsilon 2$ carrier of apoE gene was the risk factor for CHD provided that the respective individuals have high cholesterol and low HDL-C level. Similarly, carrier of $\varepsilon 3$ and $\varepsilon 4$
apoE gene were also at risk of CHD in the presense of dyslipidemia with high levels of triglycerides, total cholesterol and LDL-C and low level of HDL-C.

Table 8. Risk factor for ApoE polymorphism in triglyceride level in CHD patients and control

\begin{tabular}{lccc}
\hline $\begin{array}{c}\text { ApoE gene } \\
\text { carrier }\end{array}$ & $\begin{array}{c}\text { CHD } \\
\text { patients }\end{array}$ & Control & OR (Cl 95\%) \\
\hline TRIGLYCERIDE & & & $0.04(0,00-0.58)$ \\
$\varepsilon 2,>150 \mathrm{mg} / \mathrm{dL}$ & 1 & 8 & \\
$\varepsilon 2,<150 \mathrm{mg} / \mathrm{dL}$ & 6 & 1 & \\
$\varepsilon 3,>150 \mathrm{mg} / \mathrm{dL}$ & 6 & 0 & - \\
$\varepsilon 3,<150 \mathrm{mg} / \mathrm{dL}$ & 8 & 23 & \\
$\varepsilon 4,>150 \mathrm{mg} / \mathrm{dL}$ & 4 & 1 & $2.00(0.11-64.91)$ \\
$\varepsilon 4,<150 \mathrm{mg} / \mathrm{dL}$ & 8 & 4 & \\
\hline
\end{tabular}

Table 9. The role of ApoE polymorphism as the risk factor for CHD with controlled lipid profile.

\begin{tabular}{lcl}
\hline Carrier of ApoE gene & OR & $95 \%$ CI \\
\hline Gene $\varepsilon 2$ & 1.278 & $0.406-4.020$ \\
Gene $\varepsilon 3$ & 1.000 & - \\
Gene $\varepsilon 4$ & 4.025 & $1.207-13.418$ \\
\hline Triglyceride & 1.016 & $1.006-1.027$ \\
Gene $\varepsilon 2$ & 0.644 & $0.168-2.470$ \\
Gene $\varepsilon 3$ & 1.000 & - \\
Gene $\varepsilon 4$ & 1.016 & $1.095-14,265$ \\
\hline Cholesterol & 1.017 & $1.003-1.030$ \\
Gene $\varepsilon 2$ & 0.957 & $0.277-3.301$ \\
Gene $\varepsilon 3$ & 1.000 & - \\
Gene $\varepsilon 4$ & 4.003 & $1.140-14.052$ \\
\hline HDL-C & 0.951 & $0.908-0.996$ \\
Gene $\varepsilon 2$ & 1.126 & $0.348-3.649$ \\
Gene $\varepsilon 3$ & 1.000 & - \\
Gene $\varepsilon 4$ & 4.336 & $1.225-15.350$ \\
\hline LDL-C & 1.013 & $1.000-1.026$ \\
Gene $\varepsilon 2$ & 1.117 & $0.333-3.743$ \\
Gene $\varepsilon 3$ & 1.000 & - \\
Gene $\varepsilon 4$ & 4.119 & $1.197-14.165$ \\
\hline
\end{tabular}


This study was designed as a case control study without special treatment to control lipid profile in both groups which was later controlled by multifactorial analysis. Table 9 showed even in controlled lipid profile, $\varepsilon 4$ gene carrier has the risk factor for CHD 3.94 times higher except in triglyceride level, while the $\varepsilon 2$ gene carrier was not the risk factor for $\mathrm{CHD}$ with $\mathrm{OR}<1$.

\section{Discussion}

To demonstrate the role of $A p o E$ polymorphism as the risk factor for $\mathrm{CHD}$, the frequency of $A p o E$ gene in CHD patients was compared with controls. It was shown that \&2 allele was the protective factor for CHD and $\varepsilon 4$ allele was the risk factor for CHD. This risk factor was not different in other world populations, in which $\varepsilon 4$ gene was the risk factor for CHD than those $\varepsilon 2$ and $\varepsilon 3$ genes (Eichner et al., 2002; Elousa et al., 2004; Mahley et al., 2006; Mc. Neale et al., 2000; Pirim et al., 2001). This $\varepsilon 4$ gene was also the risk factor for myocard infarc, atherosclerosis, stroke, and neurodegeneration (Elousa et al., 2004; Frikke-Schmidt et al., 2000 (a); Guera et al., 2003; Leshinsky-Silver et al., 2006; Mahley et al., 2006; Masemola et al., 2007; Moghadasian et al., 2001; Sheehan et al., 2000; Sima et al., 2006; Yang et al., 2004). Population with high frequency of $\varepsilon 4$ allele have high incidence of ischemic heart disease and this genetic determinant was related to mortality in isolated populations (Garces et al., 2004). Different result were found in China, where polymorphism of $\varepsilon 4$ gene was not the risk factor for CHD (Liu et al., 2003), as well as in coronary artery disease. This $\varepsilon 4$ gene was not the risk factor in Oman, Greek and Brazalian populations (Al-Yahyaee et al., 2007; De Franca et al., 2004; Kolovou et al., 2002; Souza et al., 2007)

The role of apoE polymorphism in causing dyslipidemia was studied in CHD patients and controls. Apolipoprotein $\varepsilon 2$ allele has protective effect for $\mathrm{CHD}$, but $\varepsilon 3$ and $\varepsilon 4$ alleles were the risk factor for $\mathrm{CHD}$ especially in individuals with dyslipidemia. The role of apoE polymorphism on dyslipidemia in
Indonesian populations seems to be almost similar to that in the world's populations in which the $\varepsilon 2$ allele was the protective factor for CHD despite suffering from dyslipidemia (Chaaba et al., 2009; Chanprasetyothin et al., 2000; Eichner et al., 2002; Elousa et al., 2004; Mahley et al., 2006; Masemola et al., 2007; Moghadasian et al., 2001; Rodsari et al., 2005; Sheehan et al., 2000; Yang et al., 2004; Zannis et al., 1996). Other studies reported that $\varepsilon 2$ allele was related with high triglyceride level and the incidence of type III hyperlipoproteinemia (Batal et al., 2000; Bennet et al., 2007; Eichner et al., 2002; Letonja et al., 2004; Liberopoulos et al., 2004; Pallaud et al., 2001).

The role of apoE polymorphism in causing dyslipidemia is due to the ability of apoE3 to accept more cholesterol from fibroblast than apoE2 and apoE4 (Huang et al., 2009). In $\mathrm{HDL}_{3}$, apoE3 binds cholesterol better than apoE4, because the structure of carbon end domain of apoE4 was irregular and more exposed to the water; these differences causes the pathologically of cardiovascular and neurodegenerative disease (Sakamoto et al., 2008). These conditions showed that genetic factors and lipid profile varies with age, sex, and the differences of environmental factors (Pallaud et al., 2001). Studies by Eichner et al., (2002), giving hypolipidemic drugs to block HMG-CoA reductase or drugs to reduce lipid profiles, was effective for apoE $\varepsilon 2$ and apo $E \varepsilon 3$ gene carriers, but apoE $\varepsilon 4$ gene carrier was difficult to be influenced by medical intervention. Low lipid and cholesterol diets induced the decrease of cholesterol and LDL levels higher in apoE $\varepsilon 4$ gene carrier than in apoE $\varepsilon 2$ and $a p o E \varepsilon 3$ gene carriers. It was shown that response to hypolipidemic drugs was different in apoE polymorphism. Treatment with phenofibrate showed that ¿2 allele reduce lower in triglyceride level than others (Irvin et al., 2010). The defect in E4 protein, causes efficacy to bind and transport of lipid decrease. Statin drug to decrease lipid profiles was not responded by some individuals because of high response variability of hypolipidemic drugs. It can 
be summarized that the detection of genetic variability that influence lipoprotein levels in the plasma supports to predict therapeutic response (Morrison, 2007). The $\varepsilon 4$ allele is consistently lower in reduced cholesterol level after hypolipidemic therapeutic in Portugese (Withers, 2011). Regarding the effect of therapeutic intervention to modify the disease related with apoE polymorphism, apoE $\varepsilon 4$ gene carrier had the worst effect (Cacabelos et al., 2010)

As conlusion, dyslipidemia was the risk factor for CHD. Apolipoprotein $E \varepsilon 3 / \varepsilon 4$ genotype and $\varepsilon 4$ allele were the risk factor for CHD whereas apoE $\varepsilon 2 / \varepsilon 2$ genotype and $\varepsilon 2$ allele were protective factor for $\mathrm{CHD}$. Polymorphism of apoE led to variability of triglyceride level but not causes variability of other lipid profile. Apolipoprotein $E \varepsilon 3 / \varepsilon 4$ genotype and $\varepsilon 4$ allele were the risk factor for $\mathrm{CHD}$.

\section{Acknowledgements}

Theauthors appreciatefor Department of Biochemistry, Faculty of Medicine UGM and Research Center for Biotechnology UGM for providing laboratory space to carry out this work. The authors are indebted to Department of Internal Medicine, Dr. Sardjito Yogyakarta where samples were collected for this research.

\section{References}

Al-Yahyaee S.A., Ganguly S.S., Al-Kindi M.N., and Al-Bahrani A.I., 2007. Apolipoprotein E polymorphism in Omani Dyslipidemic Patients with and without Coronary Artery Disease, Hum. Biol., 79(1),93-102.

Batal R., Tremblay M., Barret P.H., Jacques H., Fredenrich A., Mamer O., Davignon J., and Cohn J.S., 2000. Plasma Kinetics of ApoCIII and ApoE on Normolipidemic and Hypertriglyceridemic Subjects,J.Lipid Res., 41,706-718

Belkovets A., Kurilovich S., Dolgich., and Agarwal D.P., 2001.Distribution of Apolipoprotein E (ApoE) Genotypes in a Siberian Female Population Sample, IJHG, 1(3),179-182
Bennet A.M., Di Angelantonio E., Ye Z., Wensley F., Dahlin A., Ahlbom A., Keavney B., Collins R., Wiman B., de Faire U., and Danesh J., 2007. Association of Apolipoprotein E Genotypes with Lipid Levels and Coronary Risk, JAMA, 298(11),1300-11.

Cacabelos R, Fernandez-Novoa L, MartinezBouza R, McKay A, Carril JC, Lombardi V, Corzo L, Carrera I, Tellado I, Nebril L, Alcataz M, Rodriquez S, Casas A, Couceiro V, Alvatez A, 2010. Future Trends in the Pharmacogeneomics of Brain Disorders and Dementia: Influence of APOE and CYP2D6 Variants, Pharmaceuticals, 3(10), 3040-3100

Chaaba N., Attia N., Hammami S., Smaoui M., Ben Hamda K.,MahjoubS., Hammami M., 2009.Association between Apolipoprotein E Polymorphism, Lipids, and Coronary Artery Disease in Tunisian type 2 diabetes, J. Clin. Lipid, 2 (5),360-364

Chanprasetyothin S., Ongphiphadhanakul B., Rajatanavin R., Siaseu N., Chailurkit L.O., and Pauvilai G., 2000. Correlation of Apolipoprotein E Gene Polymorphism to Serum Lipid Concentrations in Healthy Thais, J. Med. Assoc. Thai., 83(10),1233-9

De França E., Alves, J.G.B., and Hutz M.H., 2004. Apolipoprotein E Polymorphism and Its Association with Serum Lipid Levels in Brazilian Children, Hum. Biol., 76(2), 267-75

Eichner J.E., Kuller L.H., and Orchard T.J., Grandits G.A., McCallum L.M., Ferrel R.E., Neaton J.D., 1993. Relation of Apolipoprotein E Phenotype to Myocardial Infarction and Mortality from Coronary Artery Disease, Am J Cardiol, 71(2):160-5.

Eichner J.E., Dunn S.T., Perveen G., Thompson D.M., Stewart K.E. and Stroehla B.C., 2002. Apolipoprotein E Polymorphism and Cardiovascular Disease :A HuGE Review, Am. J. Epidemiol.,155(6),487-95

Elosua R., Ordovas J.M., Cupples L.A., Fox C.S., Polak J.F., Wolf P.A., D' Agostino Sr R.A., and O’Donnell C.J., 2004. 
Association of ApoE Genotype with Carotid Atherosclerosis in Men and Women: the Framingham Heart Study, J. Lipid Res., 45(10), 1868-1875

Frikke-Schmidt R., Tybjaerg-Hansen A., Steffensen R., Jensen G., and Nordestgaard B.G., 2000. Apolipoprotein E Genotype: Epsilon32 Women are Protected while Epsilon43 and Epsilon44 Men are Susceptible to Ischemic Heart Disease: the Copenhagene City Heart Study, J. A. Coll. Cardiol., 35(5),1192-9.

Fullerton, S.M., Clark, A.G., Weiss, K.M., Nickerson, D.A., Taylor, S.L., Stengard, J.H., Salomaa, V.,Vartiainen, E., Perola, M., Boerwinkle, E. and Sing, C.F., 2000. Apolipoprotein E Variation at the Sequence Haplotype Level Implications for the Origin and Maintenance of a Major Human, Am. J. Hum. Genet., 67,881-900

Garces C., 2004. Variations in ApoE Genotype Distribution in Children from Areas with Different Cardiovascular Disease Mortality in Spain, Hum. Biol.,76(4),615621

Guerra A., Rego C., Castro E.M., Seixas S., and Rocha J., 2003. Influence of Apolipoprotein E Polymorphism on Cardiovascular Risk Factors in Obese Children, Ann. Nutr . Metab., 47(2),49-54.

Huang Z.H., Gu D., and Mazzone D., 2009. Role of a Adipocyte-derived ApoE in Modulating Adipocyte Size, Lipid Metabolism and Gene Expression in vivo, Am. J. Physiol. Endocrinol. Metab., 296(5),1110-1119

Irvin M.R., Kabagambe E.K., Tiwari H.K., Parnell L.D., Straka R.J., Tsai M., Ordovas J.M., and Arnett D.K., 2010. Apolipoprotein E Polymorphisms and Post-prandial Triglyceridemia before and after Fenofibrate Treatment in the Genetics of Lipid Lowering and Diet Network (GOLDN) Study, Circ .Cardiovas. Genet., 3(5), 462-7

Kolovou G., Yiannakouris N., Hatzivassiliou M., Malakos J., Daskalova D., Hatzigeorgiou G., Cariolou M.A., and
Cokkinos D.V., 2002. Association of Apolipoprotein E Polymorphism with Myocardial Infarction in Greek Patients with Coronary Artery Disease, Curr. Med. Res. Opin., 18(3),118-124.

Lehtinen S., Lehtimaki T., and Sisto T.,Salenius J.P., Nikkila M., Jokela H., Koivula T., Ebeling F., and Ehnholm C., 1995. Apolipoprotein E Polymorphism, Serum Lipids, Myocardial Infarction and Severity of Angiography Verified Coronary Artery Disease in Men and Women, Atherosclerosis , 114(1),83-91.

Leshinsky-Silver E., Cheng S., Grow M.A., Shoshana S., Scharf L., Lev D., Boaz M., Brunner D., and Zimlichman R., 2006. Candidate Gene Polymorphism in Cardiovascular Disease:The BIP Cohort, IMAJ, 8(2),103-105

Letonja M., Guzic-Salobir B., Peterlin B., and Petrovic D., 2004. Apolipoprotein E Gene Polymorphism Effects Triglycerides but not CAD Risk in Caucasian Women Younger than 65 years, Ann. Genet., 47(2), 147-53.

Liberopoulos E., MiltiadousG., Hatzivassiliou M., Ayrton N., Bairaktari E., Cariolou M., and Elisaf M., 2004. Apolipoprotein E Polymorphism in Northwestern Greece: Frequency and Effect on Lipid Parameters, Ann. Clin. Lab. Sci., 34(3),347-354

Liu S., Ma J., Ridker P.M., Breslow J.L., and Stampfer M.J., 2003. A Prospective Study of the Association between ApoE Genotype and the Risk of Myocardial Infarction among Apparently Healthy Men, Atherosclerosis, 166(2),323-9

Mahley R.W., 1988. Apolipoprotein E : Cholesterol Transport Protein with Expanding Role in Cell Biology, Science, 240 (4852),622 -30

Mahley R.W., Huang Y., Weisgraber K.H., 2006. Putting Cholesterol in Its Place : ApoE and Reverse Cholesterol Transport, J. Clin. Invest.,116 (5),1226-1229

Masemola M.L., Alberts M., and Urdal P., 2007. Apolipoprotein E Genotypes and Their Relation to Lipid Levels in a Rural 
South African Population. Scand. J. Public Health Suppl., 69,60-65.

Mayes P.A. and Botham J.M., (2006), Lipid Transport and Storage, Harper's Illustrated Biochemistry, $26^{\text {th }}$ Edition, Lange Medical Books/Mc Graw- Hill : 205-216

Mc Neale P., de Knijff P., Havekes L.M., and Boomsma D.I., 2000. ApoE Polymorphism Accounts for only part of the Genetic Variation in Quantitative ApoE Levels, Genet. Epidemiol., 18, 331340

Moghadasian M.H., McManus B.M., Nguyen L.B., Shefer S., Nadji M., Godin D.V., Green T.J., Hill J., Yang Y., Scudamore C.H., and Frohlich J.J., 2001. Pathophysiology of Apolipoproein E Deficiency in Mice : Relevance to ApoE Related Disorders in Humans, The FASEB J., 15,2623-2630

Morrison J.A., Friedman L.A., and Gray-Mc Guire C., 2007. Metabolic Syndrome in Childhood predicts Adult Cardiovascular Disease 25 years later: The Princeton Lipid Research Clinics Follow-up Study, Pediatrics, 120(2),340-5

Pallaud C., Gueguen R., Sass C., Grow M., Cheng S., Siest G., and Visvikis S., 2001. Genetic Influences on Lipid Metabolism Trait Variability within the Stanislas cohort, J. Lipid Res., 42,1879-1890

Pirim I., Polat F., Akarsu E., Sahin Y.N., and Bozkurt E., 2001. Apolipoprotein E Genotyping in Patients with Coronary Heart Disease, Turk. J. Med. Sci., 31, 229 $-233$

Rodsari F.G., Borinskaya S., and Yankovsky N., 2005. Worldwide Distribution of Apolipoprotein E Gene Alleles : Is ApoE*e4 Allele a Factor of Adaptation to Climate Humans? Iranian J. Public Health, 34,62-63

Sakamoto T., Tanaka M., Vedhachalam C., Nickel M., Nguyen D., Dhanasekaran P., Phillips M.C., Lund-Katz S., and Saito H., 2008. Contributions of the CarboxylTerminal Helical Segment to the SelfAssociation and Lipoprotein Preferences of Human Apolipoprotein E3 and E4 Isoforms, Biochemistry, 47 (9), 2968-2977
Sheehan D., Bennett T., and Cashman K., 2000. Apolipoprotein E Gene Polymorphisms and Serum Cholesterol in Healthy Irish Adults: a Proposed Genetic Marker for Coronary Artery Disease Risk, Iranian J. Med. Sci.,169(1),50-4.

Sima A., Catana-Negreanua C., Albu R., Glavce C., and Vladica M., 2006. Apoliprotein EGenotype in the Romanian Population-Association with Risk Factors for Metabolic Syndrome, Proc.Rom. Acad., 8(1),19-21

Souza D.R., Nakachima L., Biagioni R.B., Nakazone M.A., Pinhel M.A., Trindade D.M., Mafra V.T., Tácito L.H., Martin J.F., Pinheiro Júnior S., and Brandão A.C., 2007. Relevance of Apolipoprotein E4 for the Lipid Profile of Brazilian Patients with Coronary Artery Disease, Braz. J. Med. Biol. Res., 40(2),189-197

Stengard J.H., Zerba K.E., and Pekkanen J., EhnholmC., Nissinen A, and SingC.F.,1995. Apolipoprotein E Polymorphism Predicts Death from Coronary Heart Disease in a Longitudinal Study of Elderly Finnish Men. Circulation, 91(2),265-269.

Stengard J.H., Weiss K.M., and Sing, C.F., 1998. An Ecological Study of Association between Coronary Heart Disease Mortality Rates in Men and the Relative Frequencies of Common Allelic Variations in the Gene Coding for Apolipoprotein E, Hum. Genet., 103(2),234-41

Wang X.L., McCredie R.M., and Wilcken D.E., 1995.Polymorphisms of the Apolipoprotein E Gene and Severity of Coronary Artery Disease Defined by Angiography. Arterioscler Thromb. Vasc. Biol., 15(8),1030-1034.

Yang S.L., He B.X., Liu H.L., He Z.Y., Zhang H., Luo J.P., Hong X.F., and Zou Y.C., 2004. Apolipoprotein E Gene Polymorphisms and Risk for Coronary Artery Disease in Chinese Xinjiang Uygur and Han Population, Chin. Med. Sci. J., 19(2), 150-154

Withers, N., 2011. Lifestyle Factors Modify Association between ApoE Genotype 
Rohmah et al.

I.J. Biotech.

and CHD, Athersclerosis, Medwire News, 26 Oct 2011

Zannis, V.I., Van de Spek, J., and Silverman D., 1996. Intracellular Modifications of Human ApoE, J. Biol. Chem., 261(29),1341513421

Zivelin, A., Rosenberg, N., Peretz, H., Amit, Y., Kornbrot, N., and Seligsohn, U., 1997. Improved Method for Genotyping Apolipoprotein E Polymorphisms by a PCR-based Assay Simultaneously Utilizing Two Distinct Restriction Enzymes, Clin. Chem., 43(9),1657-1659 